\title{
Geotechnical Characterization of soils for Use as Landfill Liner : A case study of soil samples from the Paynesville Sandstone and Farmington River Formation, Liberia
}

\author{
Y. C. Baysah ${ }^{1}$; R.S. Ngumbu²; A. K. Fayia'; A. S. Moore'; J. T. Toe Sr²., J. K. Jallah Jr². \\ ${ }^{1}$ College of Engineering, University of Liberia, Liberia \\ 2Department of Compliance \& Enforcement, Environmental Protection Agency, Liberia
}

\begin{abstract}
In Liberia, waste management is one of the main challenges faced by municipal authorities, environmental technicians and public health practitioners in their quest to maintain a clean, safe and healthy environment. The construction and operation of a sanitary landfill ensures adequate waste management and, by extension, the protection of both the environment and human receptors. This study presents the results of geotechnical investigations conducted on soils from two sedimentary units of Liberia: Paynesville Sandstone and Farmington River Formation. The intent of the study was to assess the suitability of the soil for use as landfill liner. Three soil samples were collected from each of the two sedimentary units and, using B.S 1377 (1990), soils characteristics such as particle size distribution, permeability, liquid limit, plastic limit, plasticity index and hydraulic conductivity were measured and presented as mean values. Hydraulic conductivity of a sanitary landfill liner is the most important parameter to consider in materials selection. The results of hydraulic conductivity obtained from the study showed that only the samples from Farmington River Formation met the USEPA (1994) and CGRM (2007) requirement of $\leq 1 \times 10-9 \mathrm{~m} / \mathrm{sec}$ suitable for use as landfill liner. The mean soil permeability results for the Paynesville Sandstone and Farmington River Formation were $2.5 \mathrm{~mL} / \mathrm{hr}$ and 0.05 $\mathrm{mL} / \mathrm{hr}$ respectively; implying that the samples from the Paynesville Sandstone are more permeable and, thus, more susceptible to leaching and groundwater contamination if used as a bottom liner in a landfill design. Based on the findings of this research, it can be concluded that the sample from the Farmington River Formation is more suitable for use as a natural material for landfill liner. The quality of the sample should, however, be improved by addition of small amounts of bentonite.
\end{abstract}

Keywords : Landfill liner, Paynesville Sandstone, Farmington River Formation, Liberia

\section{INTRODUCTION}

In most developing countries, efficient waste management is one of the daunting tasks faced by municipal authorities, environmentalists and public health practitioners (Khajuria, 2010). Most cities are not able to collect the total amount of Solid Waste generated and quite often only a small percentage of the waste collected are disposed properly (Firdaus,
2010). This problem is even more pronounced in Liberia due to lack of regulations, functional overlap, insufficient infrastructure and limited institutional capacity. Population growth and urban migration have presented city municipalities with a huge challenge of managing domestics and commercial wastes. Open dumping and open burning are thus the main options available to many residents of Monrovia and its environs. 
Open dumping of domestic and industrial wastes presents two inherent challenges. The most serious problem results from the passing of leachate to groundwater, which can severely contaminate soil, water resources and the surrounding environment. The second problem is the generation of gaseous pollutants like methane and carbon dioxide which contribute to global warming (IPCC, 2007).

In order to reduce the risk of groundwater and ambient pollution, engineered landfill lining systems are designed to contain both waste and its products of decomposition until they become sufficiently stable and inert to present no significant risk to humans or the environment. Engineered landfill lining systems are usually made of soils that have low hydraulic conductivity, which should not change under the action of the leachate. These soils could be compacted clay and silt. Alternative landfill lining systems have also been proposed such as geomembrane, geosynthetic clay liners and composite liners (Giroud et al, 1994).

Regardless the type of landfill design employed the quality of the materials used as bottom liners is very vital in preventing the contamination of ground water by leachates. For instance, the use of low permeability materials to line the bottom and sides of landfill is a suitable method of preventing leachates from leaking out and contaminating groundwater or surface water as well as preventing moistures from entering the landfill (USEPA, 1984).

There is currently one major land fill site in Liberia (Whein Town). A second landfill site is now under construction in Cheesemanburg. The effect of waste contamination, from the existing Whein Town landfill site, on the groundwater reserves is a subject about which there is insufficient information. There is no published quantitative study that shows the extent of leakage of pollutants into the groundwater supply. Despite this information gap, increasing population growth depicts that there may still be a need to construct more landfill sites outside of the main cities. The availability and suitability of local materials to serve as bottom liners for these proposed land fill sites remains unstudied.

This study sought to provide some options by assessing selected geotechnical characteristics (permeability, liquid limit, plastic limit, plasticity index and hydraulic conductivity) of soil samples from the Paynesville Sandstone and Farmington River Formation of Liberia. The study focuses on the suitability of soils from these two sedimentary lithological units to function as an appropriate future landfill lining system for waste disposal sites across Liberia.

The most suitable soil for landfill liners is natural clay. The effectiveness and suitability of a clay liner can be judged on the basis of two mechanisms (Jepson, 1984): The ability to impede the flow of a pollutant and pollutant carrier into the subsoil and the ability to absorb or attenuate suspended or dissolved pollutants. The main advantage of using natural clays as waste disposal landfill liners is their relatively low hydraulic conductivity and their high adsorption capacity to many hazardous substances. If the soil samples from either or both of the sedimentary units can proof to have the requisite clay content and ideal range of hydraulic conductivity, the resulting clay lining system could provide a viable option to solving some of the waste management problems in Liberia.

\section{METHODS AND MATERIAL}

\section{The Study Area}

The study was conducted at several sedimentary deposits along the Paynesville Sandstone and Farmington River Formation. The study area stretched primarily between Monrovia and Edina, with sedimentary rocks predominately concentrated 
along the coast largely below $20 \mathrm{~m}$ above sea level. The Paynesville Sandstone is less than $1 \mathrm{~km}$ thick and occurs in faulted basins near the Roberts International Airport and on the coast near Long Reef Point (White, 1969). Outcrops are also visible along the Monrovia-Kakata High way approximately $0.5 \mathrm{~km}$ from the Redlight Market. The Farmington River Formation is made up of wacke and polymict conglomerate and stretch from the Robert basin along the Farmington River to Edina. A map of the study area is provided in Figure 1.

\section{Sample Collection}

In the Case of the Paynesville Sandstone, the elevation of the sampling point was recorded and the sample was collected by first striping out the initial exposed vertical surface (those exposed by human actions or mechanical weathering) and then digging out the required amount of the samples. The sample were homogenized, placed in a polyethylene bag and coded for easy identification. The coded samples were transported to the University of Liberia Civil Engineering laboratory for analysis.

In the case of the Farmington River Formation, the sampling method employed was vertical insertion using a Soil Auger. When the sampling point was selected, the vegetation was cleared from the site. A shovel was used to create a square from which top soil was removed. The Soil Auger was then used to collect samples to a depth of $1 \mathrm{~m}(100 \mathrm{~cm})$. As in the previous case, the samples were homogenized, placed in a polyethylene bag, coded for easy identification and transported to the laboratory for analysis.

In all, a total of twelve (12) samples were collected from points across the two units within the study area. For quality control, triplicate samples were collected at each point for comparison.

\section{RESULTS AND DISCUSSION}

Particle size distribution results show that sample A (Paynesville Sandstone) has a percentage fines ( $\leq$ $1.0 \mathrm{~mm}$ ) of $42.5 \%$ (Figure 2) compared to sample B (Farmington River Formation) which recorded percentage fines $(\leq 1.0 \mathrm{~mm})$ of $59.3 \%$ (Figure 3 ). The value recorded for sample-A fell below the standard value of fines $(\geq 50 \%)$ for clay liner material (CGRM, 2007). The value reported for sample-B was within the permissible limit of fines for clay liner material reported by the same authors (CGRM, 2007).

Hydrometer analyses were conducted on the fines to determine the percentage of the clay. Hydrometer analyses show that sample A (Paynesville Sandstone) contained $10.0 \%$ of clay while sample B (Farmington River Formation) contained $49.0 \%$ of clay. It is noteworthy that Sample A fell below the standard percentage of clay specified by USDA for clay liner material $(\geq 20 \%)$ while Sample B fell within the USDA specification. However, maximum particle size of the two samples was within the value specified by CGRM, 2007. Figures 2 and 3 show the particle size distribution curves resulting from mechanical analysis (which composed of sieve analysis and hydrometer analysis) conducted on the soil samples.

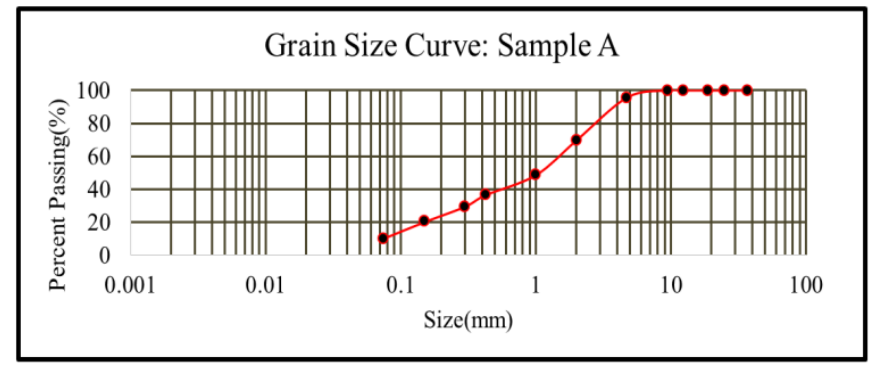

Figure 2: Mean particle size distribution curve for Samples from the Paynesville Sandstone 


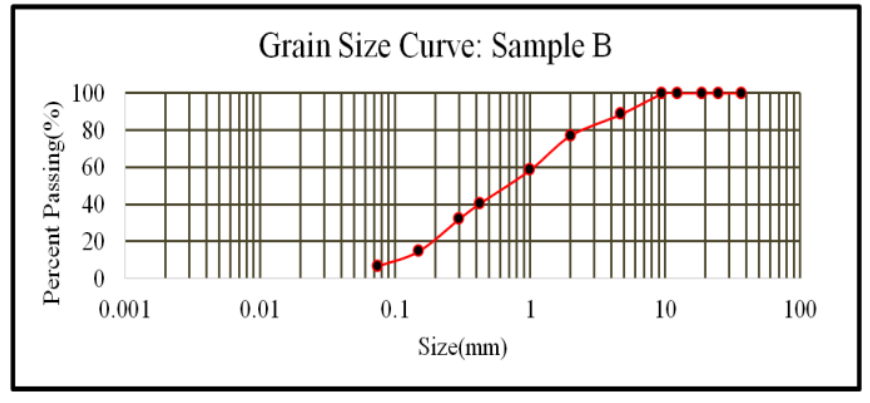

Figure 3: Mean particle size distribution curve for

Samples from the Farmington Formation

The results of Atterberg's limits are presented in Table 1. The results show sample-A, having liquid limit of $30.7 \%$, plastic limit of $17.2 \%$ and plastic index of $13.5 \%$. Sample-B had liquid limit of $34.5 \%$, plastic limit of $13.6 \%$ and plastic index of $20.9 \%$. All the samples were of adequate liquid limit value of $\geq$ $30 \%$ specified by CGRM, 2007. However, it is worth noting that only sample-B had the required plastic index as specified by CGRM, 2007 ( $\geq 20 \%)$. The soil permeability results of samples $\mathrm{A}$ and $\mathrm{B}$ were 2.5 and $0.05 \mathrm{~mL} / \mathrm{hr}$ respectively; implying that sample-A is more permeable than sample-B.

Table 1: Basic index properties tests result

\begin{tabular}{|c|c|c|}
\hline \multirow[t]{2}{*}{ Test types } & \multicolumn{2}{|c|}{$\begin{array}{c}\text { Test results } \\
\end{array}$} \\
\hline & $\begin{array}{l}\text { Sample A } \\
\text { (Paynesville } \\
\text { Sandstone) }\end{array}$ & $\begin{array}{l}\text { Sample B } \\
\text { (Farmington } \\
\text { River } \\
\text { Formation) }\end{array}$ \\
\hline $\begin{array}{l}\text { Particle size } \\
\text { distribution ( } \% \\
\text { fines) }\end{array}$ & 42.5 & 59.3 \\
\hline $\begin{array}{l}\text { Particle size } \\
\text { distribution } \\
\text { (maximum size, } \\
\text { mm) }\end{array}$ & 10.0 & 10.0 \\
\hline $\begin{array}{l}\text { Clay Content (\% } \\
\text { clay) }\end{array}$ & 10.0 & 49.0 \\
\hline $\begin{array}{l}\text { Permeability } \\
(\mathrm{mL} / \mathrm{hr})\end{array}$ & 2.5 & 0.05 \\
\hline Liquid limit (\%) & 30.7 & 34.5 \\
\hline Plastic limit (\%) & 17.2 & 13.6 \\
\hline $\begin{array}{l}\text { Plasticity Index } \\
\text { (\%) }\end{array}$ & 13.5 & 20.9 \\
\hline $\begin{array}{l}\text { Hydraulic } \\
\text { Conductivity }\end{array}$ & $3.15 \times 10^{-8}$ & $1.20 \times 10^{-10}$ \\
\hline
\end{tabular}

Results of hydraulic conductivity test conducted on the soil samples showed $3.15 \times 10^{-8} \mathrm{~m} / \mathrm{sec}$ for sampleA and $1.20 \times 10^{-10} \mathrm{~m} / \mathrm{sec}$. Hydraulic conductivity is the final test to approve the compliance of a particular soil type for use in the construction of sanitary landfill liner. When the material to be used for the construction of a liner does not meet all of the criteria stated in material characterization, additional testing are required to demonstrate that the "asconstructed" the liner will have a field hydraulic conductivity of $\leq 1.0 \times 10^{-9} \mathrm{~m} / \mathrm{s}$ as required by USEPA (1994) and CGRM (2007).

\section{IV.CONCLUSION}

The current study assessed the suitability and of soils from two sedimentary lithological units (Farmington River Formation and Paynesville Sandstone) to function as an appropriate future landfill lining system for waste disposal sites across Liberia. The results of the study showed that only Sample-B (Farmington River Formation) contains the required content of fines as reported in literature (CGRM, 2007 and Osinubi and Amadi, 2009). Sample-A (Paynesville Sandstone) showed higher silt content and lower clay content compared Sample-B. According to USEPA (1994), materials with high silt content should not be considered acceptable for use as landfill liner. Such materials would not compact well and are highly erodible. The result of the soil permeability showed that sample-B is more permeable than sample-A. Both of the samples recorded adequate liquid limits $(230 \%)$ but only sample-B had plasticity index within the limit $(\geq 20 \%)$ required by CGRM, 2007. Hydraulic conductivity of a sanitary landfill liner is the most important parameter to consider in materials selection. Even when the materials to be used as landfill liner do not meet all other requirements it can still be selected on the basis of meeting the hydraulic conductivity criterion alone. Apart from materials selection, another important factor that contributes to adequate 
performance of landfill liner is proper liner construction. Adequate quality control on the site will go a long way in improving the performance of the liner. The results obtained from the study showed that only sample-B met the required standard of hydraulic conductivity $\left(\leq 1 \times 10^{-9} \mathrm{~m} / \mathrm{sec}\right)$ suitable for use as landfill liner. Based on the findings of this research, it can be concluded that the sample from the Farmington River Formation is more suitable for use as a natural material for landfill liner. The quality of the sample should, however, be improved by addition of small amounts of bentonite.

\section{ACKNOWLEDGEMENT}

The authors extend heartfelt thanks and appreciation to Dr. Ophelia Inez Weeks, the 14th President of the University of Liberia for her continuous support to career development and research efforts. Special gratitude goes to Mr. Emmanuel O. Sherman, Deputy Minister of Operations, Ministry of Mines and Energy for his efforts in forming the original basis of this research. Special thanks also go to Dr. Nathaniel T. Blama Sr., Executive Director/C.E.O of the Environment Protection Agency (EPA) Liberia and his able Deputy, Hon. Randall Maxwell Dobayou II, for granting the authors the opportunity to use the Agency's Laboratory to carry out parts of this research. Finally, the authors extend gratitude to the Dean, Chairman and staff of the Civil Engineering Department, University of Liberia for granting the opportunity to use their laboratory for some of the experiments.

\section{REFERENCES}

[1]. BS.1377, "Methods of Testing for Soil for Civil Engineering Purpose", British Standard Institute, 389 Chiswick High Road London, W4 4AL, 1990

[2]. Canadian Government Report, Manitoba (CGRM),Technical Reference Document for
Liquid Manure Storage Structures,"Compacted Clay Liners", February, 2007

[3]. Firdaus, G (2010) Management of Urban Solid Waste Pollution in Developing Countries International Journal of Environmental Research 4(4)

[4]. Giroud, J.P., Badu-Tweneboah, K., \& Soderman, K.L. (1994). "Evaluation of Landfill Liners",Fifth International Conference on Geotextiles, Geomembranes and Related Products, Vol 3, pp981 - 986.

[5]. IPCC (2007) Climate Change 2007: The Physical Science Basis. Contribution of Working Group I to the Fourth Assessment Report of the Intergovernmental Panel on Climate Change. [S. Solomon, D. Qin, M. Manning, Z. Chen, M. Marquis, K.B. Averyt, M. Tignor and H.L. Miller (eds.)]. Cambridge University Press; Cambridge, United Kingdom 996 pp

[6]. J R. Philip (1992) Falling Head Ponded Infiltration; Water Resources Research 28(8):2147-2148

[7]. Jepson, C. P. (1984). Sodium Bentonite: still a viable solution for hazardous waste containment. Pollution Engineering, Vol. 50, pp 50- 53

[8]. Khajuria, A., Yamamoto, Y., \& Morioka, T. (2010). Estimation of municipal solid waste generation and landfill area in Asian developing countries; Journal of environmental biology, 31 5, 649-54

[9]. Osinubi, K.J. and Amadi, A. A. Hydraulic performance of compacted lateritic soilbentonite mixtures permeated with municipal solid waste landfill leachate. In: Transportation Research Board (TRB) 88th Annual meeting CD-ROM, 11-15th Jan., 2009, Washington DC, USA. Paper \# 09-0620, pp 1-1 
[10]. US Environmental Protection Agency (1994) Review of Liner and Cap Regulations for Landfills.

[11]. USEPA (1984) The Hydrologic Evaluation of Landfill Performance (HELP) Model, Volume 1. User's Guide for Version 1; "United States Environmental Protection Agency, EPA/530/SW-84-009
[12]. White, R. W., and Leo, G. W. (1969) Geologic reconnaissance in western Liberia: Liberia Geol. Survey Spec. Paper 1, 18 p., 1 pl., scale 1: 1,000,000. [1971]. --- [1971], Geologic summary of age provinces in Liberia: Geol., Mining, and Metall. Soc. Liberia Bull., v. 4 (1969-70), p. 96106. 